\title{
International Peace-Making-Creating Post-Conflict Structures of Government
}

\author{
Peter Emerson \\ The de Borda Institute, Northern Ireland \\ Email: pemerson@deborda.org
}

Received 18 January 2016; accepted 3 April 2016; published 6 April 2016

Copyright (C) 2016 by author and Scientific Research Publishing Inc.

This work is licensed under the Creative Commons Attribution International License (CC BY). http://creativecommons.org/licenses/by/4.0/

(c) (7) Open Access

\begin{abstract}
The means by which ethno-religious conflicts are resolved must themselves be "peace-ful". So arbitration must be neutral, i.e., international. And discussions must involve not just the combatants but also representatives of those in civil society who are not involved in the conflict. After much shuttle diplomacy perhaps, they must all come together to reach a settlement. In other words, they should talk with each other. If need be, they might also vote, "peace-fully", not (for-or-)against each other; indeed, most conflicts are binary, so any use of a divisive binary vote is likely to be inappropriate. Instead, they should vote, again with each other, so resort can be made, to an inclusive preferential ballot, and in fact, with such a procedure, an agreement may be more possible. In like manner, the processes by which are chosen, firstly, the above representatives of all of society, and secondly, those who will rule in the initial and subsequent post-conflict administrations, should also be peaceful. Thirdly, the system of governance must allow for the inclusion of all major groupings, and former enemies must come to some sort of arrangement in which power is shared and in which decision-making on all matters of contention involves compromise. Accordingly, this article first reflects on some of the underlying problems in majoritarian structures of governance, for these often exacerbate tensions and, in the worst scenarios, actually provoke conflict. Next, the text considers the principles on which to base a post-conflict society. And finally, it outlines a suitable political structure.
\end{abstract}

\section{Keywords}

Compromise, Consensus-Voting, Power-Sharing

\section{Introduction}

In the run-up to many conflicts, two international rights-the right of self-determination and the right of a majority to rule-have been exacerbating factors. The former (does not state but) implies that the people concerned 
shall have a binary choice, a divisive majority vote. ${ }^{1}$ The second right, majority rule, has been interpreted to mean that any majority - a grouping or faction which is based on a political ideology or maybe just on an ethno-religious commonality — can take power because they outnumber the rest, and then enact decisions by majority vote, albeit subject to certain human rights provisions.

With regard to many conflicts, the international community repeatedly calls for inclusive governance, power-sharing, or governments of national unity—all very similar phrases-yet several members of the United Nations continue to practice the very opposite, namely, majority rule.

Accordingly, having first examined how current decision-making structures are not only divisive but also inaccurate, this article considers how more sophisticated decision-making procedures can be suitable, not only for the resolution of conflicts, but also for the prevention of any recurrence. Furthermore, such procedures are able to give a more accurate assessment of the collective will. In fact it can be argued that, on occasions, the use of divisive voting procedures actually provoked violence, but these ballots were hopelessly inaccurate measures of public opinion (para 2.2). In other words, such wars could have been avoided.

\subsection{Self-Determination}

When the concept of self-determination ${ }^{2}$ was introduced by President Woodrow Wilson in 1918, during the First World War, it was seen as a means by which a subject people, not least the Belgians, could rid themselves of the occupying power or imperial ruler. In other words, it was designed as a means of solving external problems of military aggression or colonialism. It was never intended to be a basis for solving internal problems of separatism, but this is how it is often used.

Alas, in this latter role, the principle itself can be a source of conflict. This is because, in today's world, while every society has its minorities, every minority may also have one or more smaller minorities. It's like those famous Russian matryoshka dolls: as it were by definition, inside every plural society, there is at least one smaller faction. Take, for example the United Kingdom. In 1920, Ireland, a minority in the UK, opted out of the UK; whereupon Northern Ireland, NI, a minority in Ireland, opted out of Ireland; whereupon West Belfast could have opted out of NI; and so on. In effect, the right of self-determination can be vulnerable to countless interpretations and, in NI, this right actually exacerbated the conflict, "the troubles" as they were called.

In like manner, in 1991, Croatia, a minority in Yugoslavia, chose to opt out of that Federation, by referendum; whereupon the Krajina, ${ }^{3}$ a minority in Croatia, tried to opt out of Croatia and pre-empt the above Croatian secession by holding their own referendum, one week earlier. These were two mutually exclusive plebiscites, and they started a war. The question in the second one, in paraphrase, was blunt: “Are you Serb or Croat?" It was for-or-against. There was no compromise. Anyone who might have wanted to vote for compromise was, in effect, disenfranchised. So too were any partners in, and/or grown-up children of, a mixed relationship.

The lessons were unlearnt. On EU "insistence" (Woodward, 1995: p. 271), another poll was held in Bosnia, where there was no majority anyway; at that time, or so the divisive 1990 elections had implied (see para 2.2), Bosnia was 40:30:20, Moslem:Orthodox:Catholic. ${ }^{4}$ This referendum also started a war. Indeed, according to Sarajevo's main and now legendary newspaper, "all the wars in the former Yugoslavia started with a referendum" (Oslobodjenje, 7.2.1999). Similar plebiscites have been used in the Caucasus, but here too, these ballots have never helped to resolve a dispute, have always made matters deteriorate even further.

Admittedly, in some countries, such plebiscites have been peaceful. In 1905 for example, 99.9 per cent of an 84.8 per cent turnout in Norway voted to secede from Sweden. On other occasions, as in 1995 in Quebec, where two votes for independence were lost, the second one by less than one per cent, and where, in the opinion of some, the question remains, the vote was more contentious and, on this second occasion, there was some, albeit relatively minor violence. Meanwhile, in Scotland, the 2014 ballot was lost by a rather larger margin, but here

\footnotetext{
${ }^{1}$ Admittedly, some countries have exercised this right by using multi-option referendums. As a general rule, however, these jurisdictions have not been in conflict zones.

${ }^{2}$ UN Resolution 1514 (para. 2) passed in 1960, reads as follows: “All peoples have the right to self-determination; by virtue of that right they freely determine their political status and freely pursue their economic, social and cultural development.” The resolution makes no mention of how they might make such a determination, but it is usually done by a majority vote which means, of course, that the choice is not free but rather restricted to a choice of just two alternatives.

${ }^{3}$ Three areas in rural Croatia which, at the time, were largely inhabited by those of the Orthodox faith, more aligned with Serbia. In 1995, as part of the war in Bosnia, these areas were brutally "ethnically cleansed".

${ }^{4}$ Those concerned claim ethnic differences, but the three groups mentioned are all, ethnically, Slavs. The differences were religious but are, now, also historical.
} 
too, the ballot resolved nothing, and lots of Scots are already campaigning for another poll: so the Scottish referendum has become a Quebec-style "never-end-'em”, a succession of ballots until, eventually, the pro-independence side wins, by no matter how slim a margin.

In plural societies, however, as already implied, these plebiscites on sovereignty have often created or exacerbated tensions. The 1972 border poll in Northern Ireland received a Stalinist level of support from the Unionists, 98.9 per cent, and virtually none from the Nationalists; if anything, it only made "the troubles" even worse. Today, the 1994 cease-fire holds but, according to the 1998 Belfast Agreement, NI is also faced with the prospect of a "never-end-'em", a referendum every seven years or so, until eventually the Irish-side wins. So the very uncompromising question- “Are you British or Irish? Protestant or Catholic?”-which was the basis of so much violence, is now to be used in a similarly uncompromising way, as if it has somehow morphed into a nice peaceful question. It is dangerous nonsense. Imagine the scenario when the Catholic population, which is currently on the rise, overtakes the Protestant side, which is in relative decline. In theory, 50 per cent plus one is enough for a united Ireland to be enacted. If, however, just before the vote, two Catholics are murdered, then such an outcome would become 50 per cent minus one, and NI would remain in the UK (Admittedly, the decision to hold the referendum will only be taken if it is thought that the margin will be much higher. Nevertheless, the fact that this divisive methodology is in the Belfast Agreement is one of the reasons why sectarianism in NI is still at a dangerously high level).

And still the lessons remain unlearnt. When hoping to solve the civil war in Sudan, the parties involved decided to hold a plebiscite. With British diplomats in attendance, it was agreed in the Machakos Protocol of 2002 to introduce the right of self-determination into Sudan; in a word, balkanization—more dangerous nonsense. As a direct result, and within six months, there was renewed fighting in Darfur. Well of course there was! After all, if one region can fight, negotiate, and then hold a referendum to seek its objectives, why not another? The poll in South Sudan duly took place in 2011, as agreed, and a massive 97.6 per cent voted for independence; it was win-or-lose, and they won. But it is partly because politics is seen to be a win-or-lose contest that South Sudan has since imploded, and to the north, parts of Sudan itself are now also in conflict.

It is all so damned dangerous and yet the practice is so widespread. In 1947, the UN passed a resolution on Kashmir, asking for a referendum; thank heavens, it has never been held! Meanwhile, in various countries around the world, certain members of some minorities are hoping to secede, and most are campaigning for a referendum of only two-options: ${ }^{5}$ Catalonia and Basque from Spain; Corsica and maybe Brittany from France; Padania and Sardinia from Italy; Scotland from the UK and maybe, then, the Orkney Islands from Scotland; an Islamic northern Nigeria from the more Christian south; Donetsk and Luhansk, like Crimea, from Ukraine; the Tartars and Chechens from Russia; Táiwan and Xīnjiāng from China, and so it goes on. It is all, yes, damned dangerous. As currently defined and interpreted, the right of self-determination is often a provocation.

\subsection{Majority Rule}

In a very plural society, one in which no one ethno-religious grouping has a majority—a 40:30:20 Bosnia, for example-no one person can represent the (ethno-religious) majority. With binary voting, therefore, no matter who the particular leader, there might always be a majority who oppose that individual. Majority rule is part of the problem.

A current example, Syria, is even more complex. Basher al Assad is an Alawite, a minority Shia sect, so sure enough, those opposed to his rule talk of the majority. But countless factions are fighting others of a different religion, or maybe just of a different sect, or maybe of no difference at all! So no single group can rule in isolation, in peace. A settlement must, therefore, make provision for a joint presidency (para 1.2.1), the members of which should serve for only a fixed number of years.

The practice by which any one prime minister or president can choose his/her own government, appointing and sometimes dismissing ministers by will or whim, does not work well in a plural society, and could not work in any conflict zone. A more comprehensive polity is required. Accordingly, power-sharing must be another important part of any settlement. And actually, not only should posts be shared and rotated, but departments should themselves be mixed, with ministers and deputies representing most groupings and both genders. Furthermore, these ministers should not be appointed by one premier but rather chosen collectively by the entire parliament (para 1.2.2).

\footnotetext{
${ }^{5}$ One notable exception is Scotland, where many argued for a three-option poll; see footnote 11.
} 
The real test for any form of all-party governance is in decision-making. From simple policy decisions on flags, to more complex questions on economic planning, it must be possible to come to a compromise. This is difficult if the methodology of decision-making is binary, a (simple or weighted) majority vote (para 1.2.3), but it can be done in a multi-option ballot.

\subsubsection{The Presidency}

Switzerland has a seven-person Federal Council, all appointed by the top five political parties according to a so-called "magic formula" of 2:2:1:1:1. The "magic" works, but it is a methodology which perpetuates the party basis of Swiss politics, so it might not be so appropriate for a post-conflict scenario where political parties tend to be sectarian.

Lebanon operates according to the provision of the Taif Agreement, so the "President is a Maronite, the Prime Minister a Sunni [and] the Speaker... a Shia” (Fisk, 2001: p. 67), but this too emphasizes the religious differences which the said agreement was supposed to overcome.

In Bosnia, the Dayton Agreement prescribes a three-person presidency, so that each of the three religious groupings - the mainly Muslim Bosniaks, the Catholic Bosnian Croats and the Orthodox Bosnian Serbs—share the post. This arrangement is actually less conciliatory than the pre-war seven-person structure which had included two of each religious grouping plus one Yugoslav. Here too, however, as in Lebanon, the arrangements perpetuate the very divisions that had been a cause of conflict.

If rule is to be inclusive, it cannot be entrusted to only one individual. Instead, a mechanism must be devised by which a presidency can be shared by a number of persons, so to represent all major groupings in society (para. 2.3), and that mechanism should of course be ethno-colour blind.

\subsubsection{Governance}

In many conflict zones, the need for a form of all-party governance has been recognized. In NI, the Belfast Agreement caters for a power-sharing Executive in which the ten posts are shared among the most popular parties, with each party allowed to choose its ministerial posts, in order, in a process now called "cherry picking”. This provision also perpetuates the party and therefore sectarian divisions in society.

In the wake of the 2008 post-electoral violence in Kenya, the UN negotiated a power-sharing arrangement, so that both main factions could be involved, and a similar arrangement was brokered for the Democratic Republic of Congo. Again, no one party — and certainly no one party leader — should have a monopoly of power.

On 20.2.2014, the EU went to Ukraine to propose power-sharing. The incumbent President, Viktor Yanukovich, agreed... but it was all too late; on the very same day, the latter went into exile, and the country rapidly descended into a state of war.

There have been and are still many calls for inclusive governance in the Middle East, from Afghanistan, Iraq and Libya to Syria, and this may also be the pre-requisite of any solutions in Yemen and Bahrain. An ethno-colour blind methodology is urgently needed, not only viz-a-viz the appointment of the various ministers, but also for the process which precedes those appointments, the choice of a truly representative parliament (para. 2.2).

\subsubsection{Decision-Making}

The most common form of decision-making is the majority vote. It is ubiquitous. It may be a simple majority vote, with a policy proposal requiring a minimum level of support of 50 per cent plus one in order to be enacted. Or it could be a weighted vote, in which the level of support needed must pass a minimum of two thirds, three quarters, or some other fraction greater than one half; a major weakness of this form of voting is that it allows the power of veto to a minority of one third or one quarter or less, respectively.

Another form of majority voting is known as consociational. ${ }^{6}$ This requires the given electorate- the Executive in NI, the parliament in Belgium, or the entire population in Cyprus- to be divided into two different electorates, and if majorities in both support the motion, (or all three, as would be the case in Bosnia), it is passed. The obvious drawback is that, as in other forms of weighted voting, every minority grouping has the power of veto and, in "its 18-month-long existence, the [1990-2] Bosnia parliament failed to pass a single law" (Glenny, 1996: p. 148).

\footnotetext{
${ }^{6}$ There are two more types of majority voting. Twin voting is used in Swiss referendums, where success depends not only on the support of a majority of the voters but also on a majority of the cantons. The other one is qualified majority voting, as used in the EU; each member country has a certain number of votes, depending on the size of its population, and again, success is subject to a weighted threshold.
} 
The biggest drawback of all forms of majority voting, however, is as follows: nearly every debate, no matter how complex, is reduced to a dichotomy, a for-or-against question, that or a series of such binary votes. To use such a divisive methodology in a society which is already divided is at least unwise. A more pluralist approach might be better (para. 2.1), one which allows at least for the existence of other options, some of which may involve a compromise.

\section{Principles of a Post-Conflict Settlement}

An all-inclusive polity refers to a) decision-making, be it in national/regional referendums and/or in the representative chamber; b) elections or selections, either of representatives who can then negotiate a peace settlement and/or of those who will then constitute the post-settlement administration; and c) governance, the way in which a presidency and government are appointed.

\subsection{Decision-Making}

In aiming to solve any contentious dispute, the process should allow for every relevant proposal to be "on the table”. On each topic of contention, every grouping should be entitled to suggest a policy option. During the course of the debate, these policy options may be amended, and/or those who have moved a proposal may decide to form a composite, and/or another group may suggest a new idea. Accordingly, the total number of options "on the table" (a list which could be duplicated on a dedicated web-site and, in summary perhaps, on a computer screen) may vary. At the end of the debate, if in the unlikely event that the number of options has come down to a singleton, the latter may be taken to be the consensus. If not, those concerned should be enabled to cast their preferences on a (short) list of options, such that represents everything that is still "on the table".

In any debate prior to a majority vote, "Once your fall-back positions are published, you have already fallen back to them” (Eban, 1998: p. 81). If the final decision-making process is to be a preference vote, however, those concerned may express their preferences, without falling over. In fact, the very announcement of every groups’ preferences could help all concerned, not least any arbitrators, to identify a compromise acceptable to all. ${ }^{7}$

Needless to say, in any complex debate, the procedures themselves can also be fairly complex. Accordingly, it may be necessary to appoint a small team of impartial, non-voting consensors, as they are called, whose tasks are as follows:

- to decide whether or not a proposed policy option is relevant to the debate; if so, and if it complies with some previously agreed norm like the UN Charter on Human Rights, it shall be included in the debate;

- to list all the options proposed, if need be edited so that all are in the same format, on the web-page and computer screen;

- as required by the chair, to draw up a (short) list of options to be the basis of any proposed ballot;

- to display the voters' profile ${ }^{8}$ and to adjudicate on the outcome.

In the vote itself, as already noted, those concerned vote with each other. No-one votes against anybody or any policy proposal, and nobody has a veto; instead, everyone votes in favour of the various options, albeit in their individual orders of preference. Let us take the example of a five-option ballot. If a voter casts only a $1^{\text {st }}$ preference and, in effect, says nothing about the other four, he thus gives his favourite option 1 point, and nothing to any of the other options. If another voter casts two preferences, she gives her favourite 2 points (and her $2^{\text {nd }}$ preference 1 point). If yet another person casts all five preferences, he gives his favourite 5 points (his $2^{\text {nd }}$ choice 4 , his $3^{\text {rd }} 3$, etc.).

In effect, then, she who casts all five preferences gives her favourite option a 4-point advantage over the option she likes the least. So the voting procedure, the Modified Borda Count, MBC ${ }^{9}$, encourages (but does not force) the voter to participate fully in the decision-making process. In so doing, in casting preferences in favour of all the options, she recognizes the validity of every option and the aspiration of every protagonist; a necessary

\footnotetext{
${ }^{7}$ In aiming to identify a suitable compromise, a mediator or chairperson should ascertain every group's preferences, either in shuttle diplomacy or in plenary. Eventually, such a process should enable this facilitator to identify the consensus, i.e., the option which has the highest average preference. This process can be done verbally, but it can also be done via a preference vote. On subjects which are complex and/or contentious, such a vote will usually be the more practicable and transparent procedure.

${ }^{8} \mathrm{~A}$ table of all the options on one axis, and all the preferences cast by all the voters on the other.

${ }^{9}$ In a MBC of $n$ options, voters may cast $m$ preferences, where $n \geq m \geq 1$. Points are awarded to $\left(1^{\text {st }}, 2^{\text {nd }}, \ldots\right.$, last $)$ preferences cast according to the rule $(m, m-1, \ldots, 1)$.
} 
requirement, it could be argued, of any power-sharing polity.

The outcome is the option with the highest number of points. In order to get a good score, the protagonist will need not only the $1^{\text {st }}$ preferences of her own supporters, but also the $2^{\text {nd }}$ or $3^{\text {rd }}$ preferences of several others, and very few $4^{\text {th }}$ or $5^{\text {th }}$ preferences from her erstwhile (majoritarian) opponents. It is therefore worth her while, during the course of the debate, to talk to the latter, so to persuade them to give her policy option a higher preference than they had originally intended. In a nutshell, the MBC encourages dialogue and mutual respect; it is inclusive, in the fullest sense of that word.

At best, the outcome is that option which gains the highest average preference, and an average, of course, involves everyone who votes, not just a majority of them. The MBC is non-majoritarian, it is indeed very inclusive.

An option will be listed, only if someone has proposed it. In all probability, therefore, every option will get a positive score, a points total greater than zero. This total is then divided by the hypothetical maximum possible total-a $1^{\text {st }}$ preference from every voter - to calculate the option's "consensus coefficient" as it is called; it varies from 1.0, which implies unanimous support, to zero, total rejection.

Now the chances of every option getting the mean score are minimal; one or more options is/are bound to be above the mean, others below. If the winning option is way above, it may be called a (nearly) unanimous decision; if its consensus coefficient is rather less, maybe the term "consensus" would be a better description; if less still, perhaps it is only the best possible compromise; and if it is only just above the mean, then obviously other options will also be at about the same level, in which case there is no consensus and the debate should be resumed, perhaps focusing on any cluster of options which appear to be a little more popular than the rest.

The precise consensus coefficient demarcations for all the above categories must be laid down in standing orders prior to the start of the debate, especially the most important one: the minimum threshold required for a policy option to then be enacted. These demarcations can be adjusted to ensure that, before any new policy is put into law, it has widespread support in both (as in Cyprus) or all three groups (as in Bosnia) in society.

The above procedures should also apply to any referendums, especially plebiscites on sovereignty. As happened in New Zealand in 1992 where it was decided to change the electoral system, an independent commission can be tasked to receive public submissions, so to draw up a short list of options, prior to a multi-option ballot, usually on about four to six options. The NZ vote was a five-option ballot held under the rules for a two-round system, TRS. It worked: the result was a compromise, an electoral system which was half majoritarian and half proportional, the German system (see below), which is a huge improvement on that which it replaced, first-past-the-post, FPTP, a simple majoritarian ballot.

In summary, decision-making on contentious topics in post conflict societies should always cater for the possibility of compromise - that is, decision-making, be it verbal and/or voting, should not be binary, it should always be multi-optional; secondly, the methodology should be ethno-colour blind; and thirdly, to be accurate, the count must of course take account of all the preferences cast by all the voters, i.e., the methodology should be non-majoritarian.

\subsection{Elections and/or Selections}

When the ancient Greeks used electoral systems, they found that many of the candidates were not a little egotistical. So instead of voting, they used a lottery. The latter is still used in some countries for some forms of public service; in the UK, for example, persons required for jury service are chosen by lot.

Elections, however, are often preferred to selections. Somewhat surprisingly, while many people generally but incorrectly assume that decision-making has to be majoritarian, they nevertheless accept that electoral systems can and do vary enormously. At the simplistic end of the spectrum are the single preference systems held in single-seat constituencies, and these elections tend to be very adversarial; it is all win-or-lose and the outcomes are sometimes hopelessly unfair (see below, the example of Papua New Guinea). Such systems include the British FPTP, and the French TRS, which tend to produce two or perhaps three main parties.

The more common forms of proportional representation, PR, such as the Dutch PR-list system are single preference systems held in multi-seat constituencies, so the Netherlands have quite a few political parties. In Greece and Italy, however, the winning party gets a number of bonus seats, so to (render a proportional system very dis-proportional but so to) ensure the leading party has an outright majority of seats.

In the middle of the spectrum, there are variations on these themes such as the German system, which is half FPTP and half PR-list, or the Danish two-tier system which consists of two PR-list counts. So the Germans tend 
to have two big parties and two or three smaller ones, while the Danes, like the Dutch, have many parties.

At the more sophisticated end of the range are the multi-preference systems like the Australian alternative vote, AV, which caters for preferential voting in single-seat constituencies; this rather less adversarial system tends to encourage some co-operation between some of the candidates. The more win-win-and therefore more "peace-ful"- systems are preferential ballots held in multi-seat constituencies, and these include the Swiss version of PR-list, the Irish proportional version of AV, the single transferable vote, PR-STV, and another methodology, the quota Borda system, QBS (see below).

In a conflict zone, as it were by definition, any single-preference system is inadequate. The 1996 post-war elections in Bosnia, for example, held under a closed single-preference PR-list system, were just sectarian headcounts, just as had been the 1990 elections, held under TRS. In September of that fateful year, "Polls had [Ante] Marković and his reform league on top... with 25.9 per cent" (Woodward, 1995: p. 448), but the electoral system was single preference, so many people voted for "one of their own" and as a result, the three sectarian parties got higher than expected results. This trio then "formed a grand coalition to defeat the reform communists and Marković's reformists on the second round" (ibid: 122). In other words, just like the win-or-lose majority referendum (para 1.1), that electoral system was a cause of war. Therefore, in any peace settlement, at least those in society who want to be "peace-ful" must be enabled to be so; that is, they must be allowed to cross the party if not the sectarian divides. In a word, the electoral system must be preferential, and the voters must be allowed to cast preferences.

The system used in NI, PR-STV, enables the voters to do exactly that, to cross that party/sectarian/gender divides, but unfortunately, many people choose not to. Papua New Guinea used to have FPTP but, in such a multi-tribal society, most votes were cast on a tribal basis, and in a constituency of over twenty candidates, the winner was sometimes elected on less than five per cent of the vote (Emerson, 2012: p. 63). Accordingly, they have now changed the system to AV, with the added proviso that voters must cast at least three preferences. In effect, then, for a vote to be valid, the individual must cross the tribal divide at least twice.

In theory, Lebanon also has a "peace-ful" system, a multiple form of FPTP. In a constituency which is, say, 30:30:30, Maronite:Shia:Sunni, every political party wishing to stand must nominate candidates in groups of three, one of each; and every voter must vote for three candidates, again, one of each. This too is a brilliant system, at least in theory (but not always in practice; on some occasions, mediocre candidates can get elected on the coat-tails of a more prominent politician).

As seen in par a 2.1, the MBC is very inclusive; it is not, however, proportional. Accordingly, for any election, an adaptation of the MBC known as QBS should be used. As in PR-STV, the mathematics of a QBS count also encourage every grouping to nominate only as many candidates as it thinks it can get elected, so in a hypothetical 30:30:30 constituency electing six representatives, each could expect two or, at the most, three nominees to be chosen. At the same time, as in an MBC, voters are incentivised to cast a full ballot. Accordingly, if the election asks the electorate to cast six preferences, the voters will be encouraged to cross the sectarian divide at least once. Success in a QBS election depends on a good number of top preferences and/or a good MBC score. As in decision-making, therefore, candidates would be well advised to seek support from outside their own groupings. This too, surely, is an important requirement of any peaceful procedure.

\subsection{Governance}

Not only western parliaments but communist powers as well have long since regarded majority rule as rudimentary. In fact, in the former Soviet Union, the very word "bolshevik" meant "member of the majority". Furthermore, there is an almost ubiquitous yet mistaken assumption that a majority opinion can be identified or at least ratified by a majority vote.

Paradoxical as it may appear, this is often not the case, not least because a majority opinion has to be identified earlier if it is to be already on the ballot paper. It might be possible in a small gathering like the UN Security Council in which there are only 15 members; ${ }^{10}$ but it is not possible in a parliament of hundreds, let alone a society of millions! At best, the majority vote is not an identification process but one of ratification. But in many plebiscites, a majority vote is a means by which those in power set the question and thereby control the debate; such votes have been used by the likes of Napoleon, Lenin, Mussolini, Hitler and others (Emerson, 2012: pp.

\footnotetext{
${ }^{10}$ At the end of the 2002 debate on Resolution 1441 on Iraq, both France and Germany voted in favour, yet neither supported the inclusion of the phrase "serious consequences". To suggest, then, that the said resolution was passed with unanimous support was at least disingenuous. Binary voting is a blunt instrument.
} 
143-153).

In fact, the two-option majority vote is the most inaccurate measure of collective opinion ever invented. It cannot measure consensus because it measures the very opposite-so many for and so many against-the degree of dissent. Furthermore, logically, a collective will cannot be identified if some of the voters are not expressing their own individual wills, i.e., if some of them are only speaking negatively, saying what they do not like, voting only "no".

A collective will can be identified, however, in a multi-option, preferential vote, a ballot in which every voter expresses his/her opinion positively, voting, albeit in order of preference, only for those options of which he/she is in favour. Politics should not be a top-down procedure in which the prime minister of the day-Tudjman in Croatia, Cameron on Scotland, ${ }^{11}$ for example-chooses the question and in which the question is probably the answer. ${ }^{12}$ Instead, every grouping in parliament should be allowed to contribute to the debate; everything should be "on the table"; and (a short list of) everything should be on any subsequent ballot paper.

The MBC is not majoritarian. As implied above, at best, it identifies the option with the highest average preference, and an average, of course, involves everyone who votes, not just a majority of them. In many cases, just as a unanimous opinion has majority support, so too a consensus opinion might also be a majority viewpoint. On really contentious topics, however, the two measures may give two different outcomes; indeed, when everything is on the table and when a short list is on the ballot paper, there may not be majority support for any one option; there might nevertheless be a consensus opinion.

The conclusion is huge: if the collective will of parliament can be identified via an MBC, there will be no further justification for that which has been a cause of so much conflict-majority rule by majority vote. ${ }^{13}$ Instead, just as a parliament or congress should represent everyone in society, so too, a government or politbureau should represent not just the bigger "half" but the collective whole. Accordingly, once elected, parliament or congress should elect or select its multiple presidency and its executive; in a post-conflict society, the methodology must be ethno-colour blind.

This could be a PR election in which the successful are appointed, in order of popularity, to a pre-arranged list of portfolios. This might have the disadvantage, however, that a farmer is appointed to look after the finances while an economist is chosen to care for agriculture. A more appropriate methodology would be the QBS matrix vote (Emerson, 2016: pp. 79-102). It is a tabular ballot in which the voters, the members of the parliament or congress, choose, in their order of preference, not only those whom they wish to see in cabinet, but also the particular ministry in which they wish each of their nominees to serve. There is one ballot but two counts. The first is a QBS election to find, on the basis of top preferences and/or MBC totals, the required number of most popular members; and the second is an MBC election to see, on the basis of points cast per portfolio, which of these most popular members should be appointed to which ministry.

As in the MBC and QBS, so too in the matrix vote, every member is encouraged, by the very mathematics of the count, to cross the sectarian divide. A group with 40 per cent of the members can expect to win about 40 per cent of the posts, so there is little point in casting preferences for group colleagues for more than 40 , or at the most 50, per cent of the seats available. At the same time, it is advisable to submit a full ballot. In other words, every member is thus encouraged to cross the group, party and/or sectarian divides. This too could be regarded as a pre-requisite of any peace settlement voting procedure.

\section{Conclusion}

At the moment, there are huge disparities in the world's peace settlements. South Africa set up a time-limited Truth and Reconciliation Commission. In Bosnia, certain individuals were accused of war crimes and sent to the Hague. In Northern Ireland, there was no Truth Commission and, seemingly, while thousands of crimes had

\footnotetext{
${ }^{11}$ The 2014 debate in Scotland was multi-optional, consisting of three options: the status quo, maximum devolution and independence. Thinking initially that independence would lose in a straight status quo versus independence contest, Cameron decided on a two-option ballot. Later on, however, polls suggest that the second option, maximum devolution, was the most popular by far. But because it was not on the ballot paper, it may be assumed that one if not both of the other two options received highly inflated levels of support. In any multi-option debate, binary voting can be and often is hopelessly inaccurate.

${ }^{12}$ Only one dictator has ever lost a referendum: Augusto Pinochet in Chile won his first two plebiscites in 1978 and '80, but lost by 57.0 per cent when he tried to extend his term as President in 1988.

${ }^{13}$ In days long gone, many Chinese people believed in the mandate of heaven and many westerners adhered to the divine right of kings. Both we now know, were mistaken. In the not too far distant future, the right of majority rule by majority vote, majoritarianism, may also come to be seen as a right that was wrong.
} 
been committed, there were no war criminals as such; instead, some of those whom many in society thought were implicated in the violence became ministers in the new power-sharing Executive.

A further difference lies in the use of referendums. As noted above, a plebiscite on NI's constitutional status is a major feature of the Belfast Agreement. At the same time, similar referendums have been totally ruled out of order in Bosnia's future.

While most place a reliance on a form of PR in elections-PR-STV in NI, usually only single-preference PR-list elsewhere- one unfortunate common feature in many accords is the use of (a form of) majority voting in decision-making. As already implied, binary decision-making has been a cause of countless disputes and yet this majority voting, on which majority rule is so often based, is often retained, albeit in its consociational format. Admittedly, some peace agreements mention consensus, but none talk of consensus voting.

One further common feature is power-sharing. The form chosen usually involves an all-party form of governance. Sadly, however, peace settlements rarely if ever allow for preferential voting in decision-making. Instead, as noted, they continue to rely on simple majority voting or, at best, consociational majority voting; so everything remains dichotomous.

There is a need, therefore, for international norms to be established. Every conflict has its own nuances, of course, but settlements should involve preferential and proportional elections to choose those who will then negotiate a settlement; a similarly ethno-colour-blind methodology of appointing/electing an executive and maybe too a joint presidency/politbureau; and thirdly, for use in both the appointed chamber and in referendums, a preferential form of decision-making.

There is, furthermore, another overwhelming necessity: for those in stable societies who preach power-sharing and inclusive governance, to first and foremost put it into practice.

\section{References}

Eban, A. (1998). Diplomacy for the Next Century. Yale: Yale University Press.

Emerson, P. (2012). Defining Democracy. Heidelberg, Dordrecht, London, New York: Springer. http://dx.doi.org/10.1007/978-3-642-20904-8

Emerson, P. (2016). From Majority Rule to Inclusive Politics. Heidelberg, Dordrecht, London, New York: Springer http://dx.doi.org/10.1007/978-3-319-23500-4

Fisk, R. (2001). Pity the Nation. Oxford: Oxford University Press.

Glenny, M. (1996). The Fall of Yugoslavia. London: Penguin.

Woodward, S. (1995). Balkan Tragedy. Washington: The Brookings Institute.

\section{Abbreviations}

$\begin{array}{ll}\text { AV } & \text { Alternative vote } \\ \text { BC } & \text { Borda count } \\ \text { EU } & \text { European Union } \\ \text { FPTP } & \text { First-past-the-post } \\ \text { MBC } & \text { Modified Borda count } \\ \text { NI } & \text { Northern Ireland } \\ \text { NZ } & \text { New Zealand } \\ \text { PNG } & \text { Papua New Guinea } \\ \text { PR } & \text { Proportional representation } \\ \text { PR-STV } & \text { PR-single transferable vote } \\ \text { QBS } & \text { Quota Borda system } \\ \text { TRS } & \text { Two-round system } \\ \text { UK } & \text { United Kingdom } \\ \text { UN } & \text { United Nations }\end{array}$

